\title{
Resistance training might have improved insulin resistance by attenuating sarcopenia
}

Clinical Interventions in Aging

8 December 2015

Number of times this article has been viewed

\author{
Yildiray Topcu' \\ Fatih Tufan ${ }^{2}$ \\ M Akif Karan' \\ 'Department of Geriatrics, Istanbul \\ Faculty of Medicine, ${ }^{2}$ Department \\ of Gerontology, Faculty of Medical \\ Sciences, Istanbul University, Istanbul, \\ Turkey
}

\section{Dear editor}

We read the valuable article of Oliveira et al ${ }^{1}$ entitled "Resistance training improves isokinetic strength and metabolic syndrome-related phenotypes in postmenopausal women" with interest. In their well-designed prospective study, the authors observed improvement in metabolic syndrome-related phenotypes after 12 weeks of resistance training. We have some comments that could facilitate interpretation of the results of this study.

Because muscle mass is an important target for glucose uptake, sarcopenia seems to be an emerging risk factor for insulin resistance in elderly individuals. ${ }^{2,3}$ Resistance training is among the most important measures to attenuate sarcopenia. ${ }^{4,5}$ Thus, we suggest that there may be a close relationship between improvement in muscle mass and strength and reduction in insulin resistance in this study. At least some of the individuals in this study $(90.3 \pm 24.1 \mathrm{Nm})$ seem to have sarcopenic muscle strength considering the muscle strength measurements of a sarcopenic obesity group $(87.5 \pm 17.8 \mathrm{Nm})$ in a previous study from Brazil. ${ }^{6}$ After the resistance training intervention, the muscle strength of the study population $(101.9 \pm 21.4 \mathrm{Nm})$ is similar to the non-sarcopenic obese group $(96 \pm 23.4 \mathrm{Nm})$ in the previous study. Thus, transition from sarcopenia to normal muscle mass and functions is a rational explanation to the improvement in insulin resistance in this study. We suggest that the authors assess the relationship between delta-homeostatic model assessment-insulin resistance (delta-HOMA-IR) and delta-muscle strength. Furthermore, a multivariate regression analysis might also be performed to seek independent factors underlying improvement of insulin resistance (delta-HOMA-IR). These analyses may provide clinically relevant information.

\section{Disclosure}

The authors report no conflicts of interest in this work.

\section{References}

1. Oliveira PF, Gadelha AB, Gauche R, et al. Resistance training improves isokinetic strength and metabolic syndrome-related phenotypes in postmenopausal women. Clin Interv Aging. 2015;10:1299-1304.

2. Perkisas S, Vandewoude M. Where frailty meets diabetes. Diabetes Metab Res Rev. Epub 2015 Oct 9.

3. Lee SW, Youm Y, Lee WJ, et al. Appendicular skeletal muscle mass and insulin resistance in an elderly Korean population: the Korean social life, health and aging project-health examination cohort. Diabetes Metab J. 2015;39(1):37-45.

4. Csapo R, Alegre LM. Effects of resistance training with moderate vs heavy loads on muscle mass and strength in the elderly: a meta-analysis. Scand J Med Sci Sports. Epub 2015 Aug 24.

5. Zembron-Lacny A, Dziubek W, Rogowski L, Skorupka E, Dabrowska G. Sarcopenia: monitoring, molecular mechanisms, and physical intervention. Physiol Res. 2014;63(6):683-691.

6. Oliveira RJ, Bottaro M, Junior JT, Farinatti PT, Bezerra LA, Lima RM. Identification of sarcopenic obesity in postmenopausal women: a cutoff proposal. Braz J Med Biol Res. 2011;44(11):1171-1176. 
Dove Medical Press encourages responsible, free and frank academic debate. The content of the Clinical Interventions in Aging 'letters to the editor' section does not necessarily represent the views of Dove Medical Press, its officers, agents, employees, related entities or the Clinical Interventions in Aging editors. While all reasonable steps have been taken to confirm the content of each letter, Dove Medical Press accepts no liability in respect of the content of any letter, nor is it responsible for the content and accuracy of any letter to the editor.

Clinical Interventions in Aging

Dovepress

\section{Publish your work in this journal}

Clinical Interventions in Aging is an international, peer-reviewed journal focusing on evidence-based reports on the value or lack thereof of treatments intended to prevent or delay the onset of maladaptive correlates of aging in human beings. This journal is indexed on PubMed Central, MedLine,

CAS, Scopus and the Elsevier Bibliographic databases. The manuscript management system is completely online and includes a very quick and fair peer-review system, which is all easy to use. Visit http://www.dovepress. com/testimonials.php to read real quotes from published authors.

Submit your manuscript here: http://www.dovepress.com/clinical-interventions-in-aging-journal 